\title{
ИДЕОЛОГИЯ ЛИТЕРАТУРЫ
}

DOI 10.22455/2541-8297-2019-14-228-251

УДК 821.161 .1

\section{Н.А. Полевой и ІІІ отделение}

\author{
( ) 2019, А.И. Рейтблат
}

\begin{abstract}
Аннотация: Цель статьи - обобщить уже известные сведения о контактах Н.А. Полевого с III отделением, ввести в научный оборот ряд новых документов по данной теме, в том числе переписку Н.А. Полевого и начальника III отделения А.Х. Бенкендорфа, и на этой основе дать характеристику контактов литератора с политической полицией. III отделение занималось главным образом наблюдением за поведением и отношением к власти и ее политике различных слоев общества, а также формированием «общественного мнения». Для этой цели оно стремилось взять под свой контроль журналистов. В статье показан, что в случае с Н.А. Полевым III отделение успешно решило стоявшую перед ним задачу: руководители отделения лично устно и письменно указывали ему на отклонения от «верных» взглядов, а также поощряли морально и материально (с помощью регулярных денежных выплат). В результате, если в начале деятельности Полевого критика отдельных недостатков и призывы к реформам сочетались у него с восхвалением монарха и России (причем скорее не ее прошлого и настоящего, а будущего), то позднее он отказался от критики и писал в основном тексты, полезные режиму - панегирические монархические статьи и исторические монархическо-патриотические книги и пьесы. Более того, он был благодарен царю и III отделению за поддержку. Представленные в статье факты вносят важные уточнения в историю взаимоотношений журналистики и власти в первой половине XIX в.

Ключевые слова: ІІІ отделение, Н.А. Полевой, А.Х. Бенкендорф, Л.В. Дубельт, литература и власть.
\end{abstract}

Информация об авторе: Абрам Ильич Рейтблат, канд. пед. наук, «Новое литературное обозрение» / Российская государственная библиотека искусств, Москва, Россия. E-mail: reitblat@nlo.magazine.ru

Цитирование: Рейтблат А.И. Н.А. Полевой и III отделение // Литературный факт. 2019. № 4 (14). С. 228-251. DOI 10.22455/2541-8297-2019-14-228-251 
Основной задачей III отделения, вопреки широко распространенным представлениям, было не столько подавление протестов против существующего строя, сколько «профилактика»: сбор информации о происходящем в стране, главным образом о «направлении умов», а также влияние на общественное мнение с целью обеспечить порядок и спокойствие. Для этой цели III отделение стремилось взять под свой контроль журналистов, причем делало это достаточно гибко. Если Министерство народного просвещения, которое, казалось бы, должно способствовать развитию в стране журналистики и литературы, довольно жестко пресекало любые отклонения от официальной линии с помощью цензуры, а в период руководства С.С. Уварова инициировало закрытие ряда изданий («Московский телеграф», «Телескоп»), то руководители III отделения, с одной стороны, «журили» журналистов в случае «ошибок», а с другой — заказывали им нужные материалы. Весьма наглядно это демонстрируют связи III отделения с редакторами газеты «Северная пчела» Ф.В. Булгариным и Н.И. Гречем ${ }^{1}$.

Хорошим примером подобной политики являются и отношения III отделения с Н.А. Полевым. В данной работе мы ставим целью обобщить уже известные сведения о контактах Полевого с III отделением, ввести в научный оборот ряд новых документов по данной теме и на этой основе дать характеристику этих контактов.

Полевой с 1825 г. издавал журнал «Московский телеграф», в котором увлеченно и талантливо отстаивал идеи романтической эстетики и романтической историографии, а также, в пределах допустимого, реформирования политического и экономического строя России. М.К. Азадовский отмечал, что «основными пунктами его программы были ликвидация крепостного права, раскрепощение промышленности и расширение правового положения “третьего сословия"» ${ }^{2}$. Полевой был сторонником всеобщего просвещения, развития промышленности и науки, приобщения к достижениям европейской цивилизации ${ }^{3}$. Журнал его имел большой успех у читателей и вызывал настороженное, а временами и враждебное отношение правительственных кругов.

\footnotetext{
См.: Видок Фиглярин: Письма и агентурные записки Ф.В. Булгарина в III отделение / Публ., сост., предисл. и коммент. А.И. Рейтблата. М., 1998; Рейтблат А.И. Наблюдательный Наблюдатель: Н.И. Греч и III отделение // Литературный факт. 2018. № 10. С. 108-164.

Азадовский М.К. История русской фольклористики: В 2 т. М., 2013. Т. 1. С. 235.

${ }^{3}$ См.: Шикло А.Е. Исторические взгляды Н.А. Полевого. М., 1981. С. 27-35.
} 
Возлагая надежды на реформы, Полевой не был не только революционером, но даже оппозиционером. Он являлся сторонником постепенного развития как экономики, так и самого русского общества; «идеал Полевого - просвещенная, заботящаяся о благе своего государства монархия, сила которой “в уважении, в привязанности народов"» ${ }^{4}$.

Вот как он излагал свою программу в предисловии к роману «Клятва при гробе Господнем»:

Судьба русской земли необыкновенна тем, что Русь поставлена между Югом и Севером, между Европою и Азиею, обширна, могущественна, но младшая сестра всем другим европейцам. До Петра Русь возрастала отдельно от Запада: была в Европе и вне Европы. Только Петр начал настоящее образование Руси. Форма сего образования долженствовала быть европейская, $a$ не азиатская <...>. Прошло уже сто лет, как мы вдвинуты в Европу, но - только вещественно. <...> по умственному образованию - мы всех европейцев моложе, мы еще дети!

$<\ldots>$ Мы производители, мы должны помогать правительству, создавая русскую промышленность, русское воспитание, русскую литературу, словом - русское внутреннее образование, или проявление внутренних сил России. Для этого необходимо: 1-е, и начальное: искреннее сознание у нас существующих недостатков; 2-е, справедливое сознание чужеземных преимуществ; 3-е, верное познание сущности самих себя; 4-е, умение пользоваться чужим хорошим, отвергая чужое дурное. $<\ldots>$ Мы победили Европу мечом, мы победим ее и умом: создадим свою философию, свою литературу, свою гражданственность, под сению славного престола великих монархов наших $!^{5}$

В своих публикациях на политические темы Полевой неизменно панегирически отзывался об императоре и проводимой им внешней и внутренней политике. Вот показательные высказывания 1828 г.: «Ни одно государство в мире не представляется нам ныне в виде столь славном и исполненном стольких надежд. Юный государь и новые поколения русских вступили на поприще истории, и вступление их ознаменовалось в сильных и решительных порывах». Перечислив как военные победы, так и действия по упрочению законности, развитию промышленности, торговли и сельского хозяйства, а также

4 Там же. С. 45.

5 Полевой Н.А. Клятва при гробе господнем: Русская быль XV века. М., 1832. Ч. 1. C. XII, XV-XVI, XXVI. 
науки и просвещения, Полевой заключал: «...друг человечества с радостью замечает повсюду подвиги Монарха, деятельного и неусыпно думающего о благе подданных, столько же, сколько о государственной чести России и военной славе ее» ${ }^{6}$.

Выступая, как и близкие ему по взглядам Булгарин и Греч, против дворянства, прежде всего аристократии, Полевой возлагал все надежды на царя, надеясь, что тот ограничит дворянские притязания и будет способствовать экономическому (т.е. буржуазному) развитию России. Названные журналисты, критикуя «либеральное» (оппозиционное, но на самом деле скорее консервативное) дворянство в лице пушкинского круга литераторов, поддерживали программу постепенных экономических и, частично, политических преобразований в России ${ }^{7}$. В этом глубинная причина доверия к ним со стороны руководителей III отделения, частично разделявших эту программу. Ведь Николай I проводил (особенно в начале царствования) реформы, направленные на кодификацию законодательства, развитие экономики и системы образования, поддержку купечества, облегчение положения крестьян. При этом он с некоторым недоверием относился к дворянству, из среды которого вышли декабристы, и больше доверял заинтересованному в нем купечеству и вообще «народу».

Разумеется, доверие III отделения к Полевому не было «полным»: в случае «промахов» и «ошибок» Полевого, как и издававших официозную «Северную пчелу» Греча и Булгарина, ждали замечания, выговоры, а иногда и более строгие наказания. Так, когда в 1829 г. Полевой поместил в № 14 «Московского телеграфа» сатирический очерк «Приказные анекдоты», в котором речь шла о том, как чиновники обманывают малокомпетентных губернаторов, Николай, ознакомившись с ним, дал Бенкендорфу указание, чтобы начальник Московского округа корпуса жандармов генерал А.А. Волков вызвал к себе Полевого и пропустившего статью цензора С.Н. Глинку

\footnotetext{
${ }^{6}$ [Полевой Н.] Историческое обозрение первой половины 1828 года// Московский телеграф. 1828. Ч. 22. № 13. С. 157, 164-165. Об авторстве Полевого см.: Шикло А.Е. Указ. соч. С. 50. Близкие по содержанию и по тону оценки деятельности Николая I см.: [Полевой Н.] Взгляд на 1829 год // Московский телеграф. 1830. Ч. 31. № 1. С. $110-111,119,121$; [Полевой Н.] Историческое обозрение 1830 года // Московский телеграф. 1831. Ч. 37. № 1. С. 114, 116.

Подробнее о политических взглядах Полевого, Булгарина и Пушкина см.: Орлов Вл. Николай Полевой — литератор тридцатых годов // Николай Полевой: материалы по истории русской литературы и журналистики тридцатых годов. Л., 1934. С. 20-37; Рейтблат А.И. Пушкин как Булгарин: к вопросу о политических взглядах и журналистской деятельности Ф.В. Булгарина и А.С. Пушкина // Рейтблат А.И. Фаддей Венедиктович Булгарин: идеолог, журналист, консультант секретной полиции: статьи и материалы. М., 2016. С. 57-91.
} 
и предупредил, что «при первом случае, когда появится вновь такого рода статья, то поступлено будет с ними по закону» ${ }^{8}$, а Глинке сделал строгий выговор. Полевой в ответ написал А.А. Волкову объяснительную записку, где уверял, что имел в виду только «общественную пользу и славу монарха русского», извинялся за свой невольный проступок и просил:

Чтобы извлечь надлежащую пользу для общества из критических статей о нравах, и с тем вместе действовать сообразно намерениям и воле правительства, да позволено мне будет отныне прежде обыкновенной цензуры подвергать статьи сего рода <..> цензуре особенной, доставляя их для рассмотрения к вашему превосходительству. Я осмеливаюсь думать, что тогда ревность моя действовать сочинениями к исправлению нравов и тем споспешествовать благодетельным видам правительства не вовлечет меня в неумышленную ошибку <..>. Во всем этом, ваше превосходительство, изволите видеть искреннее желание: согласить пользу посильных трудов моих с сохранением порядка общественного. Как русский, пламенно любящий славу монарха, видящий в нем не только государя, но и великого, гениального человека нашего времени, я уверен, что его светлый ум знает и ценит все, даже и малейшие средства действовать на подвластный ему народ, сообразно мудрым его предначертаниям9

Письмо это Бенкендорф доложил царю, а тот на докладе наложил резолюцию: «Дозволить г. Волкову рассматривать критические статьи» ${ }^{10}$. Полевой получил возможность защититься от возможных строгостей цензуры и гарантию от преследований за подобные публикации в дальнейшем.

Другие публикации в «Московском телеграфе» также нередко вызывали недовольство властей. В том же 1829 г. министр народного просвещения К.А. Ливен поручил попечителю Московского учебного округа А.А. Писареву «поставить на вид» Московскому цензурному комитету за пропуск напечатанной в № 10 «Московского телеграфа» лекции французского философа Кузена по философии, поскольку эта лекция «заключает в себе вредное учение о вере и философии» ${ }^{11}$.

8 Цит по: Николай Алексеевич Полевой, его сторонники и противники по «Московскому телеграфу» / Сообщил Н.Д. [Н.Ф. Дубровин] // Русская старина. 1903. № 2. C. 263.

9 Там же. С. 264.

10 ГАРФ. Ф. 109. Оп. 221. Ед. хр. 15. Л. 47. После смерти А.А. Волкова в 1833 г. в «Московском телеграфе» (№ 12. С. 517-533) была помещена написанная А.Я. Булгаковым его панегирическая биография.

${ }_{11}$ Щукинский сборник. М., 1903. Т. 2. С. 302-303. 
Тем не менее, когда в 1830 г. Николай неделю (7-12 марта) пробыл в Москве, подготовить подробное описание этого визита поручили Н. Полевому. Он сочинил очень «прочувствованный» верноподданнический текст, основным лейтмотивом которого были любовь народа к царю и любовь царя к народу:

Наши русские сердца говорят нам, что нынешнее пребывание Государя Императора в Москве отрадно было Его великой душе: светлый сердечным удовольствием взор Его высказывал сию утешительную мысль, при каждом воззрении нашем на Надежду-Государя $<. .>$ Народ видел Царя своего, и - это великодушие, эта внушающая благоговение, неизъясняемая кротость и простота, с какою всюду являлся, всюду виден был Повелитель шестой части света возвышали и умиляли душу ${ }^{12}$.

Представляя рукопись статьи Бенкендорфу, Полевой писал ему 22 марта:

Ваше Высокопревосходительство Милостивый Государь!

Слабое изображение того, что мы видели, что мы думали в счастливое для нас время пребывания Государя Императора в Москве, честь имею представить при сем и почитаю себя счастливым, что мне суждено сказать, что чувствуют все обитатели Москвы.

Вижу ясно весь недостаток моих дарований для исполнения подобного долга и осмеливаюсь надеяться только на благосклонное снисхождение Вашего Высокопревосходительства и моих соотечественников. Если, при пламенном желании, я успел передать слову, хотя несколько, голос души - я почту себя красноречивым, даже и при малых моих дарованиях.

С истинным высокопочитанием и глубокою преданностию, честь имею быть Вашего Высокопревосходительства Милостивого Государя покорнейший слуга Николай Полевой ${ }^{13}$.

Присланная статья, судя по всему, вполне удовлетворила заказчика. По крайней мере, она была передана в «Северную пчелу» и напечатана там без каких-либо изменений.

Отношение Бенкендорфа к Полевому хорошо характеризует частное письмо, с которым 8 февраля 1832 г. он обратился к Полевому по поводу публикации в «Московском телеграфе» (1831. № 16) рецензии

${ }^{12}$ Письмо из Москвы от 19 марта // Северная пчела. 1830. Прибавление к № 39. 1 апр. Опубл. без подписи.

${ }_{13}$ ГАРФ. Ф. 109. 1 эксп. 1830. Ед. хр. 120. Л. 5. 
на брошюру «Горе от ума, производящего всеобщий революционный дух, философически-умозрительное рассуждение, сочинение S.». Бенкендорф утверждал, что данная рецензия - «это не литература, а совершенное суждение о высшей политике», что в ней Полевой утверждает, «что революции необходимы и <..> польза революций очевидна для потомства» и что «только непросвещенные мыслители могут жаловаться на бедствия, происходящие от оных!» Он писал:

Я не могу не скорбеть душою, что во времена, в кои и без ваших вольнодумных рассуждений юные умы стремятся к общему беспорядку, вы еще более их воспламеняете и не хотите предвидеть, что сочинения ваши могут и должны быть одною из непосредственных причин разрушения общего спокойствия. Писатель с вашими дарованиями принесет много пользы государству, если он даст перу своему направление благомыслящее, успокаивающее страсти, а не возжигающее оные ${ }^{14}$.

Одновременно Бенкендорф в официальном отношении министру народного просвещения К.А. Ливену указал, что Полевой и издатель журнала «Телескоп» Н.И. Надеждин распространяют «идеи самого вредного либерализма» ${ }^{15}$.

В ответном письме от 21 февраля Полевой писал:

Ваше Высокопревосходительство Милостивый Государь!

Горестно было бы получить письмо, которым Ваше Высокопревосходительство удостоили сообщить мне замечания Ваши об одной статье «Телеграфа», если бы не видел я из того же письма, с каким снисходительным вниманием Вы изволите различать неумышленную ошибку, или недоразумение, от виновной злонамеренности, и как отечески храните не только честь, но даже спокойствие самого незначительного человека, хотя все дает повод обвинить его по наружности. - «Велик и благодетелен Монарх, достоин Монарха сановник Его!» - таковы были чувства мои по прочтении письма Вашего Высокопревосходительства.

В грустном молчании долженствовал бы я внять Вашим замечаниям и составить из них правила для себя на предбудущее время; но слова Вашего Высокопревосходительства «желал бы я иметь ваше объяснение, с какою целью, с каким намерением вы позволяете себе печатать столь вредные мнения для общего блага» - заставляют меня отнестись к Вам с моею покорною просьбою. 
Подобного объяснения я имел счастие испрашивать в бытность Вашу в Москве и готов представить его Вам, не как обыкновенному блюстителю порядка, но как Сподвижнику Великого, обожаемого мною Государя, человеку души высокой и истинно-благородной, Мужу государственному, для которого не существует ничто мелкое и низкое. Все мысли мои так чисты, вся жизнь моя так оправдывает меня, что объяснения с Вашим Высокопревосходительством я не только не страшусь, но желаю, как ручательства за свое доброе имя и спокойствие, мое и многочисленного моего семейства.

По собственным делам моим на сих днях я отправляюсь в С. Петербург. Позвольте мне, Ваше Высокопревосходительство, лично предстать в С. Петербурге к Вам, позвольте говорить с Вами прямо и откровенно. Если после того Ваше Высокопревосходительство не продолжите Вашего ко мне уважения — я готов подвергнуться всякому наказанию.

С истинным, глубоким почтением и совершенною преданностью честь имею пребыть Вашего Высокопревосходительства Милостивого Государя покорнейший слуга Николай Полевой ${ }^{16}$.

Приведенное письмо проясняет, как представляется, истоки той приязни, которую в дальнейшем питал Бенкендорф к Полевому, тех неформальных отношений, которые возникли между ними. Полевой позиционировал себя в них в качестве представителя народа, пламенного патриота, обожающего царя и готового исполнять все повеления власти. Он даже архаизировал язык своих писем и прошений, чтобы усилить соответствующее впечатление. При этом он всячески (прибегая в том числе и к откровенной лести) подчеркивал свое подчиненное положение и стремление следовать «отеческим» указаниям Бенкендорфа.

Через три месяца, в апреле 1832 г., Полевой хотел поднести императору составленный им сборник «Новый живописец общества и литературы», составленный из сатирических очерков и пародий, печатавшихся в одноименном приложении к «Московскому телеграфу» ${ }^{17}$. Он обратился к Бенкендорфу, тот направил соответствующее отношение к Ливену, но Ливен отказал, мотивировав это тем, что данная книга «никакой пользы ни языку, ни словесности принести не может» и «является спекуляцией книгопродавца» ${ }^{18}$.

16 ГАРФ. Ф. 109. 1 эксп. 1830. Ед. хр. 120. Л. 1-2. В.Н. Орлов полагал, что «ответного письма Полевого не сохранилось» (Николай Полевой... С. 475).

${ }^{17}$ Новый живописец общества и литературы, составленный Николаем Полевым. Ч. 1-6. М., 1832.

${ }^{18}$ Цит. по: Козмин Н.К. Очерки из истории русского романтизма. СПб., 1903. C. 503. 
В марте 1833 г. министром народного просвещения стал С.С. Уваров, принципиальный противник Полевого. Он говорил: «Я знаю, чего хотят наши либералы, наши журналисты и их клевреты: Греч, Полевой, Сенковский и проч. Но им не удастся бросить своих семян на ниву, на которой я сею и которой я состою стражем, - нет, не удастся. Мое дело не только блюсти за просвещением, но и блюсти за духом поколения. Если мне удастся отодвинуть Россию на 50 лет от того, что готовят ей теории, то я исполню мое дело и умру спокойно» ${ }^{19}$.

Уже в мае 1833 г. в рецензии Н. Полевого на книгу Вальтера Скотта «Жизнь Наполеона Бонапарте, императора французов» (Московский телеграф. 1833. № 9) Уваров нашел «самые неосновательные и для чести русских и нашего правительства оскорбительные толки и злонамеренные иронические намеки» ${ }^{20}$. За пропуск рецензии был уволен цензор И.А. Двигубский, цензурный контроль за «Московским телеграфом» усилился, а 24 сентября Уваров подал царю записку с предложением запретить журнал. Однако Николай не согласился, посчитав это чрезмерным. Тем не менее он распорядился «Полевому объявить, чтоб вздору не писал: иначе запретится журнал его» ${ }^{21}$, что и было ему объявлено в Москве 29 октября 1833 г.

Однако после публикации в феврале 1834 г. отрицательной рецензии на чрезвычайно высоко оцененную царем «патриотическую» пьесу Н.В. Кукольника «Рука всевышнего отечество спасла» (Московский телеграф. 1834. № 3) Полевого по приказу царя привезли в Петербург. Сразу же по прибытии он представил Бенкендорфу оправдательную записку, в которой утверждал, что критиковал пьесу только с литературной точки зрения, не выступая против «патриотической цели автора» ${ }^{22}$. В ходе расследования обстоятельств публикации рецензии Уваров всячески стремился дискредитировать Полевого, в то время как Бенкендорф прилагал усилия к тому, чтобы приуменьшить его «вину» и облегчить его участь 23 . Полевой писал И.М. Снегиреву в это время: «...после личного объяснения с графом Бенкендорфом выговор назван был недельным. Всё произошло от

${ }^{19}$ Цит. по: Никитенко А.В. Дневник. Л., 1955. Т. 1. С. 174.

20 Цит. по: Сухомлинов М.И. Исследования и статьи по русской литературе и просвещению. СПб., 1889. Т. 2. С. 402.

21 Там же. С. 403.

22 Николай Алексеевич Полевой, его сторонники и противники по «Московскому телеграфу». С. 268.

${ }^{23}$ См.: Николай Полевой... С. 316-330, 479-483. 
перетолкований; но граф всегда был и будет лично благородным и добрым человеком ${ }^{24}$.

По мнению К.А. Полевого, брата Н.А. Полевого, Уваров «непременно хотел обвинить гонимого им журналиста и, вероятно, в таком смысле составил доклад о нем, то есть представил его человеком опасным по образу мыслей <..>. Не так думал о брате моем граф Бенкендорф, обращавшийся к нему не как Уваров и, наконец, давший ему возможность оправдать себя в мнении правительства единственно добрыми своими отзывами о нем» 25 .

В результате журнал всё же был запрещен 3 апреля 1834 г., но лично против Полевого никаких репрессивных мер принято не было (в отличие от Н.И. Надеждина, которого после запрета его журнала «Телескоп» в 1836 г. сослали в Усть-Сысольск) $)^{26}$.

Полевой стал редактировать выходивший отдельными выпусками иллюстрированный сборник «Живописное обозрение», причем Уваров не позволил ему стать официальным редактором, и даже подписывать статьи своим именем было ему в это время запрещено. В конце апреля 1835 г. Николай вновь приехал с Бенкендорфом в Москву. Бенкендорф спросил у сотрудника III отделения Н.А. Кашинцова, в обязанности которого входило наблюдение за выходящими в Москве периодическими изданиями, чем занимается Полевой. Тот ответил, что Полевой сотрудничает в «Живописном обозрении» и показал выпуск сборника со статьей «Памятник Петра Великого» ${ }^{27}$. Статья эта, которая, как справедливо отмечал Вл. Орлов ${ }^{28}$, близка по духу к активно пропагандируемой в это время С.С. Уваровым теории официальной народности, понравилась Бенкендорфу, тот представил ее царю, который также одобрил ее и поручил изъявить Полевому свое благоволение ${ }^{29}$. Полевому было поручено подготовить описание посещения царем промышленной выставки в Москве ${ }^{30}$. Знакомым Полевой говорил, что поручение это исходило от императора ${ }^{31}$. Как

\footnotetext{
${ }^{24}$ Цит. по: Козмин Н.К. Указ. соч. С. 526.

25 Николай Полевой... С. 330.

26 Обзор цензурных репрессий по отношению к «Московскому телеграфу» см.: Березина В.Г. Журнал Н.А. Полевого «Московский телеграф» и цензура // Вестник Санкт-Петербургского университета. Сер. 2. История, языкознание, литературоведение. 1996. Вып. 3. С. 71-81.

27 Живописное обозрение. М., 1835. Л. 14. С. 105-111.

${ }^{28}$ См.: Николай Полевой... С. 487.

${ }^{29}$ См.: Там же. С. 334-336.

30 См.: Полевой H. Посещение Московской выставки произведений отечественной промышленности Государем Императором // Северная пчела. 1835. № 131-134. 14, 15, 17, 18 июня. Об этой статье см.: Осповат А.Л., Тименчик Р.Д. «Печальну повесть сохранить...». М., 1985. С. 47-51.

${ }^{31}$ См.: Снегирев И.М. Дневник. М., 1904. Т. 1. С. 199.
} 
вспоминал К.А. Полевой, «во всех последующих сношениях своих с Николаем Алексеевичем граф Бенкендорф действовал с неизменным доброжелательством к нему, и даже, когда случалось ему (и не один раз после этого) делать выговоры неосторожному писателю, он старался щадить и ободрять в нем человека», «не один раз, во время приездов своих в Москву, призывал его к себе, рассуждал с ним очень любезно о разных предметах, поручал составлять статьи о пребывании государя императора в Москве, и вообще обходился с ним, как с человеком уважаемым и отнюдь не подозрительным для правительства $\rangle^{32}$.

В январе 1836 г. Полевой представил Бенкендорфу записку о том, что собирается писать многотомную историю Петра I и просит разрешить посвятить ее Николаю I, а также предоставить ссуду для подготовки материалов и издания. Прославляя Петра, он изображал Николая его наследником, который начал новый период русской истории, и обещал, что в книге «образ современного будет отражаться на каждой странице бытописаний прошедшего, светом которого сияет настоящее» ${ }^{33}$.

Бенкендорф доложил царю о записке Полевого и представил включенный в нее план будущей книги. Николай наложил резолюцию: «Историю Петра Великого пишет уже Пушкин, которому открыт архив Иностранной коллегии; двоим в одно время поручить подобное дело было бы неуместно...» ${ }^{34}$ Отвечая Полевому 25 января, Бенкендорф писал, что «Его Величество с благоволением удостоил принять Ваше намерение; но не мог вполне изъявить Монаршего соизволения на все Ваши предположения по той причине, что начертание истории Петра поручено уже известному литератору нашему А.С. Пушкину, которому, вместе с тем, представлены и все необходимые средства к совершению сего многотрудного подвига». Бенкендорф прибавлял: «...по моему мнению, посещение архивов не может заключать в себе особенной для Вас важности, ибо ближайшее рассмотрение многих Ваших творений убеждает меня в том, что, обладая в такой степени умом просвещенным и познаниями глубокими, Вы не можете иметь необходимой надобности прибегать к подобным вспомогательным средствам» ${ }^{35}$.

В ответ Полевой писал Бенкендорфу 27 января следующее:

\footnotetext{
${ }^{32}$ Николай Полевой... С. 336, 352.

33 Лемке Н.К. Николаевские жандармы и литература 1826-1855 гг. СПб., 1909. C. 102.

${ }^{34}$ Там же. С. 102.

35 Русский архив. 1874. № 4. Стб. 1050-1052. Хотя под письмом стоит подпись Бенкендорфа, но не исключено, что текст его был написан Дубельтом. По крайней
} 
Сиятельный граф, Милостивый Государь!

Со слезами радости получил я ответ Вашего Сиятельства. Да благословит Бог православного Царя нашего! Да благословит Бог и Вас, достойный его болярин! Кладу руку на русское сердце, из него беру эти слова, внушаемые мне чувством благодарного умиления, и умоляю Вас, Сиятельный Граф, повергнуть их к стопам праправнука Петра Великого. Отныне часы уединения моего, жизнь моя будут посвящены тому, чтобы оправдать делом, чего не могу теперь выразить словами. Гений Петра вдохновит меня - Царь Русский увидит, что способен сделать последний из его подданных, одушевленный приветом Его. Это не гордость, Сиятельный Граф, - это сознание силы русской души, вспыхнувшей жарко и неугасимо.

С истинным, глубочайшим почтением и совершенною преданностию, имею счастие пребыть Вашего Сиятельства Милостивого Государя покорнейший слуга Николай Полевой ${ }^{36}$.

В августе 1836 г. Николай вновь прибыл с Бенкендорфом в Москву, и Полевому вновь заказали подготовить описание пребывания Николая в Москве; оно было помещено без подписи в «Московских ведомостях» (1836. № 67) ${ }^{37}$.

Тем не менее доверием Полевой не пользовался. В конце 1837 г. он переехал в Петербург, поскольку Смирдин взял в аренду у Греча и Булгарина «Северную пчелу», купил у них журнал «Сын отечества» и предложил Полевому с 1838 г. редактировать эти издания. Однако Уваров не дал согласия на то, чтобы Полевой был официальным их редактором. Он стал редактировать их неофициально, но через несколько месяцев Греч и Булгарин вынудили его отказаться от редакторства в «Северной пчеле», и у Полевого остался только «Сын отечества», где большую часть материалов он публиковал без подписи (в первой половине 1840 г. он покинул и «Сын Отечества»). При этом, по свидетельству сына, «все статьи Н[иколая] А[лексееви] ча, в корректуре, доставлялись из цензурного комитета в III отделение, где их просматривал Л.В. Дуббельт, всегда относившийся

мере позднее оно было повторно опубликовано как письмо Дубельта, см.: Русская старина. 1897. № 11. С. 385.

${ }^{36}$ ГАРФ. Ф. 109. СА. Оп. 1. Ед. хр. 1915.

37 Об авторстве Полевого см. следующее свидетельство И.И. Дмитриева в письме П.П. Свиньину от 22 октября 1836 г.: «Знаю <..> по слухам, что журнал о пребывании здесь Императора и помещенный в "Московских ведомостях", писан им, и будто по поручению графа Блудова» (Дмитриев И.И. Соч. СПб., 1895. Т. 2. С. 327). О контактах Полевого с Бенкендорфом в период после запрета «Московского телеграфа» см.: Лейбов Р. Немецкий путешественник о Н.А. Полевом // Труды по русской и славянской филологии. Литературоведение. І. (Новая серия). Тарту, 1994. C. 242-254. 
к Н[иколаю] А[лексееви]чу чрезвычайно гуманно» ${ }^{38}$. Полевой ценил это и в письмах к брату называл управляющего III отделением (с 1839 г.) Дубельта «добрейшим», «человеком, каких немного» ${ }^{39}$.

В 1841-1842 гг. Полевой негласно редактировал «Русский вестник» (в 1841 г. совместно с Н.В. Кукольником и Н.И. Гречем, который в эти годы был его издателем и официальным редактором), печатал он также в «Библиотеке для чтения», «Северной пчеле» и других изданиях прозу и пьесы, исторические работы, литературно-критические статьи и бесчисленные рецензии, но все эти публикации уже не содержали критических высказываний и были выдержаны в духе пропаганды православия, самодержавия и народности (в 1840 г. он прямо писал, что «мудрое правительство указывает нам на три основы нашего народного быта, православие, самодержавие и народность $<\ldots>\gg)^{40}$.

В Петербурге Полевой много писал для театра, главным образом историко-патриотические пьесы. В ноябре 1838 г. Николай посетил премьеру «Дедушки русского флота». Полевой писал брату, что Бенкендорф вызвал его к себе и передал следующее: «Государь благодарит вас, велел сказать вам, что он никогда не сомневался в необыкновенных дарованиях ваших, но не предполагал в вас такого сценического искусства. Он просит вас, приказывает вам писать для театра. Давайте мне все, что вы напишете, Государь сам будет всё читать». Кроме того, Бенкендорф от лица царя вручил Полевому бриллиантовый перстень стоимостью около 2,5 тыс. рублей ассигнациями ${ }^{41}$ (один рубль серебром был равен 3,5 рубля ассигнациями). И в дальнейшем Николай поощрял драматургические опыты Полевого, в частности, в 1840 г. одобрил к представлению «Парашу Сибирячку», которую театральная цензура не хотела пропускать, поскольку в числе действующих лиц был Александр I.

12 сентября 1839 г. Полевой обратился к Бенкендорфу со следующей просьбой:

Сиятельный Граф, Милостивый Государь!

Желая принесть хоть малую лепту сердечного сочувствия великому празднеству бородинскому и с тем вместе участвовать, чем

${ }^{38}$ Дневник Н.А. Полевого // Исторический вестник. 1888. № 3. С. 667. (Примеч. П.Н. Полевого).

39 Цит. по: Записки Ксенофонта Алексеевича Полевого. СПб., 1888. С. 389, 447.

40 Полевой Н. Взгляд на русскую литературу 1838 и 1839 годов // Сын Отечества. 1840. Т. 1. Отд. 4. С. 444.

41 Записки Ксенофонта Алексеевича Полевого. С. 445-446. 
могу, в благотворительных подвигах Ваших, осмеливаюсь всепокорнейше Вас, Сиятельный Граф, просить:

Удостоить внимания Вашего прилагаемую при сем составленную мною «Повесть о великой битве Бородинской», и если она будет осчастливлена Вашим одобрением, удостоить ее испрошением Высочайшего соизволения:

1-е. Напечатать ее на казенный счет, в числе 2400 экземпляров.

2-е. Часть сих экземпляров (примерно 400) определить для раздачи в военно-учебных заведениях, ибо я осмеливаюсь думать, что упомянутая Повесть составит для них занимательное и назидательное чтение.

3-е. Остальные затем экземпляры пустить в продажу и вырученные, за расходами на печатание, деньги обратить в Детскую больницу ${ }^{42}$, для употребления их по усмотрению Вашему. Драгоценный для каждого русского предмет моего сочинения дает надежду, что все число экземпляров легко будет распродано, а я счастливым себя почту, если тем хоть несколько успею доказать ревностное желание мое споспешествовать преуспеянию благодетельного заведения, Вашему начальству вверенного.

С истинным почтением и совершенною преданностью честь имею пребыть, Сиятельный Граф, Вашего Сиятельства Милостивого Государя, покорнейший слуга ${ }^{43}$.

Бенкендорф ходатайствовал перед императором и получил его согласие (л. 3$)^{44}$.

1 сентября следующего года Полевой обратился к Дубельту (Бенкендорф в это время сопровождал императора в путешествии по России) с новой просьбой:

\section{Ваше Превосходительство Милостивый Государь!}

Многие из литераторов и почтенных любителей русской словесности изъявили мне желание: слышать теорию и практику словесности, изложенные мною в публичных чтениях, по примеру того, как читаемы были курсы разных наук и знаний г-ми Остроградским,

42 Имеется в виду Императорская Николаевская детская больница, открытая в 1834 г. Одним из инициаторов ее создания был Бенкендорф; Николай I назначил его пожизненным попечителем больницы.

${ }^{43}$ ГАРФ. Ф. 109. 1 эксп. 1839. Ед. хр. 269. Л. 1-1 об. (Далее ссылки на это дело даны в скобках в тексте статьи.) На письме рукой Дубельта написано: «Граф на всё согласен. Доклад Государю».

44 О благодарности Полевого Дубельту, Бенкендорфу и царю см.: Записки Ксенофонта Алексеевича Полевого. С. 510. Однако книга вышла только через несколько лет: Полевой Н.А. Повесть о великой битве Бородинской, бывшей 26 августа 1812 года. СПб., 1844. 
Гессом, Соколовым, Бутырским, Усовым, Озанном, Гречем, Моннероном $^{45}$ и другими. Охотно соглашаясь на их желание и полагая, что могу довольно удовлетворительно исполнить его, после 20-летних занятий теориею и практикою словесности, я не смел однако ж ничего обещать, не испросивши предварительного разрешения Вашего Превосходительства.

Представляя при сем составленную мною общую Программу предполагаемого курса ${ }^{46}$, покорнейше прошу Ваше Превосходительство удостоить меня Вашим разрешением о том: могу ли я приступить к публичному извещению о чтениях моих? - Касательно подробностей честь имею донести, что получив позволение Ваше, предполагаю я немедленно приготовить мои чтения и открыть их с октября месяца сего 1840 года, с определенною платою за билет для слушания их. Всех чтений предполагаю я до 18-ти, так, чтобы читаемые еженедельно, они могли кончиться к февралю будущего года. Предмет их, как Ваше Превосходительство изволите усмотреть из Программы, составят собственно теория и практика словесности, с удалением от всяких посторонних предметов. Кроме того, каждое чтение может быть предварительно быть представляемо мною для особенного рассмотрения по назначению Вашему.

Осмеливаюсь думать, что предприятие мое, соединяя в себе приятное общественное занятие с пользою, удостоится благосклонного внимания Вашего. Откровенно должен я притом признаться, что предполагаемые чтения будут служить для меня и семейства моего весьма важным пособием в настоящее время, весьма для меня стеснительное, ибо никакими другими литературными трудами не могу я ныне заняться и отказался даже от всякого участия в журналах, как по причине совершенно расстроенного моего здоровья, а тем более что остальные силы и исключительную работу посвящаю я одному огромному труду моему - Истории Петра Великого. Начавши ее, как известно Вашему Превосходительству, в 1835 году, продолжал я с тех пор, хотя и медленно, но постоянно и беспрерывно, и теперь

45 Упомянуты математик и механик, академик Петербургской академии наук (1830) Михаил Васильевич Остроградский (1801-1861); химик, академик (1834) Герман Иванович Гесс (1802-1850); геолог и минералог, профессор Петербургского университета (1822-1844) Дмитрий Иванович Соколов (1788-1852); литературовед и эстетик, поэт, ординарный профессор Петербургского университета (1826-1835) Никита Иванович Бутырский (1783-1848); экстраординарный профессор Петербургского университета, специалист по сельскому хозяйству Степан Михайлович Усов (1796-1859); немецкий химик и физик, профессор Дерптского университета (1823-1828) Готтфрид Вильгельм Озанн (1796-1866); журналист, писатель, филолог и педагог Николай Иванович Греч (1787-1867); преподаватель французского языка и декламации в Воспитательном доме и частных пансионах Карл Моннерон (1790-е — 1857), который в 1839 г. читал публичные лекции о приложении географии к истории.

46 Программа сохранилась: ГАРФ. Ф. 109. 1 эксп. 1839. Ед. хр. 269. Л. 9-10 об. 
привожу уже к окончанию, так что к будущему году надеюсь вполне ее окончить. Начало ее было осчастливлено, при покровительстве Его Сиятельства Графа Александра Христофоровича, Высочайшим вниманием, и по благополучном ее окончании буду я иметь честь просить просвещенного и благодетельного предстательства Его Сиятельства в том, чтобы повергнуть уже оконченный труд мой к Священному Престолу Государя Императора - единственная награда, которой желаю, которой стремлюсь достигнуть.

С истинным, глубочайшим почтением и совершенною преданностью честь имею пребыть, Вашего Превосходительства Милостивого Государя покорнейший слуга Николай Полевой (Л. 7-8).

Бенкендорф не хотел давать разрешения, но в то же время не желал, чтобы Полевой обиделся на него. Поэтому 13 сентября Дубельт написал Полевому, что Бенкендорф счел, что по этому вопросу Полевому следует обратиться к Уварову (л. 11). Одновременно он направил письмо Уварову с просьбой до беседы с ним не давать ответ Полевому. 15 ноября Уваров написал Бенкендорфу, что, поскольку журнал Полевого «Московский телеграф» запрещен из-за «неблагонамеренного направления», «едва ли удобно дозволить ныне г. Полевому чтение публичных лекций, и в особенности лекций о русской словесности, долженствующих привлечь значительное число слушателей, без полного убеждения в совершенной благонадежности его образа мыслей». Далее он продолжал: «Впрочем, если Ваше Сиятельство имеете положительные сведения, что г. Полевой переменил прежнее свое направление и в хорошем образе мыслей его нельзя более теперь сомневаться, то на основании Вашего мнения можно бы было дозволить ему беспрепятственно просимое чтение лекций» (л. 13a). В результате 20 ноября Бенкендорф ответил, что согласен с мнением Уварова и считает, что «Полевому неудобно позволить читать публичные лекции о российской словесности» (л. 14).

В январе 1841 г. император, узнав о болезни и трудном материальном положении Полевого, повелел выдать ему 2 тыс. рублей ассигнациями в качестве единовременного вспомоществования ${ }^{47}$.

Сделав вывод, что отношение императора к нему улучшилось, в марте того же года Полевой вновь через Бенкендорфа обратился с просьбой допустить его в архивы для завершения работы над историей Петра I. Бенкендорф, изложив в докладе императору 13 марта просьбу Полевого, добавил от себя: «Я читал доставленное мне Полевым начало его Истории Петра Великого; оно очень хорошо

${ }^{47}$ См.: Лемке М.К. Указ. соч. С. 131. 
и написано в таком духе и таким слогом, что нельзя не желать, чтобы ему доставлена была возможность вполне развернуть талант свой. а потому я осмеливаюсь просьбу Полевого о дозволении осмотреть здешние и московские архивы повергнуть на Всемилостивейшее воззрение Вашего Императорского Величества» ${ }^{48}$. Однако Николай, несмотря на ходатайство Бенкендорфа, разрешения вновь не дал ${ }^{49}$.

Хотя никаких агентурных услуг III отделению Полевой не оказывал, но литературный союз его с Гречем и Булгариным и направление его литературной деятельности рождали в публике подозрения. Кроме того, о контактах Полевого с Бенкендорфом стало известно в литературной среде, и там сделали свои выводы об их характере. По крайней мере, А.С. Пушкин в мае 1836 г. в письме жене называл его, как и Булгарина, «шпионом» III отделения ${ }^{50}$. А.А. Краевский в 1839 г. писал Белинскому о Полевом: «Каналья, который не перестает писать доносы на всех честных людей, обнимаясь с Булгариными и Кукольниками» ${ }^{51}$. М.А. Дмитриев посвятил Полевому стихотворный перепев баллады Жуковского под названием «Новая Светлана», написанный, по-видимому, в 1840 г., где есть такие строки:

Венедиктович Фадей (Булгарин. - A.P.)
Пишет: «Вы, как друг людей,
С нами равной масти.
Я хочу вам предложить:
Не согласны ли служить
По секретной части» ${ }^{52}$.

В бумагах умершего в 1844 г. влиятельного сановника, бывшего министра народного просвещения и духовных дел князя А.Н. Голицына нашлась записка, в которой говорилось, что он собирается ходатайствовать у императора о ежегодном денежном пособии Н. Полевому «во уважение трудов его на поприще русской литературы» и того, что Полевой «при многочисленном семействе не имеет никакого состояния». Записка эта через III отделение была представлена Николаю. По его поручению III отделение собрало различные сведения о Полевом и подготовило справку, где был упомянут один выговор Полевому по линии III отделения и вызов его в Петербург в 1834 г. перед запретом

${ }^{48}$ ГАРФ. Ф. 109. Оп. 221. Ед. хр. 84. Л. 41.

49 См.: Лемке М.К. Указ. соч. С. 132. Книга вышла из печати в 1843 г.: Полевой Н.А. История Петра Великого. Ч. 1-4. СПб., 1843.

${ }^{50}$ Пушкин А.С. Письма последних лет. Л., 1969. С. 141.

51 В.Г. Белинский и его корреспонденты. М., 1948. С. 97.

52 Русский архив. 1885. № 4. С. 658. 
журнала, но итоговый вывод гласил, что «кроме сего не было случаев, которые клонились бы не в пользу г. Полевого, напротив, он, как прежде, так и впоследствии, неоднократно обращал на себя монаршее внимание полезными его литературными сочинениями, коими он доказал верноподданническую преданность и любовь к Всеавгустейшему дому и Отечеству». Император, ознакомившись с докладом, 21 февраля 1845 г. распорядился выдать Полевому 1 тыс. рублей серебром «в виде негласного пособия и ежегодно возобновлять это пособие, ежели он того будет заслуживать» ${ }^{53}$. Выдача денег Полевому осуществлялась через III отделение. Подобные выплаты пособий писателям через это учреждение осуществлялись и ранее. Так, в 1832 г. по докладу А.Н. Голицына С.Н. Глинке было пожаловано ежегодное пособие в 3 тыс. рублей ассигнациями, с выдачей после его смерти денег жене и дочерям до смерти последней из них ${ }^{54}$, а 1842 г. по представлению (через Бенкендорфа) попечителя Московского учебного округа графа С.Г. Строганова Николай распорядился выплатить Гоголю 500 руб. серебром $^{55}$.

Информируя Полевого о повелении царя, Дубельт писал 7 марта 1845 г.:

Николай Алексеевич!

В бумагах покойного действительного тайного советника 1-го класса князя Голицына найдена была подписанная им записка, из которой видно, что он предполагал ходатайствовать перед Государем Императором о доставлении вам пособия, в уважение трудов ваших на поприще русской литературы и крайне недостаточного вашего состояния, и Его Императорское Величество, по всеподданнейшему докладу генерал-адъютанта графа Орлова ${ }^{56}$ всемилостивейше соизволил пожаловать вам в виде негласного пособия тысячу рублей серебром.

По воле графа Алексея Федоровича Орлова с живейшим удовольствием уведомляя об этом вас, милостивый государь, и препровождая при сем означенные деньги, имею честь покорнейше просить вас о получении оных почтить меня уведомлением.

Пользуюсь случаем уведомить вас в искреннем моем к вам уважении и совершенной преданности.

Л. Дубельт ${ }^{57}$.

53 ГАРФ. Ф. 109. 2 эксп. 1845. Ед. хр. 73. Л. 7. Часть материалов дела опубликована: К биографии Н.А. Полевого // Русская старина. 1897. № 7. С. 103-107.

${ }^{54}$ ГАРФ. Ф. 109. 2 эксп. 1845. Ед. хр. 73. Л. 1.

${ }_{55}^{5}$ См.: Лемке М.К. Указ. соч. С. 135-136.

56 А.Ф. Орлов возглавил III отделение после смерти Бенкендорфа в 1844 г.

57 ГАРФ. Ф. 109. 2 эксп. 1845. Ед. хр. 73. Л. 11. 
Полевой отвечал ему:

Ваше Превосходительство Милостивый Государь!

Имевши честь получить письмо Ваше и при нем всемилостивейше пожалованные мне Государем Императором тысячу рублей серебром, могу ли сказать что-либо иное, кроме того, что Высочайшее благодеяние, имя благодетельного старца, подавшего к тому повод, и участие, принятое в том Его Сиятельством, Графом Алексеем Федоровичем, и Вами, останутся навсегда запечатленными в сердце моем. Молю Бога, чтобы Он дал случай мне или детям моим доказать, что милость Монарха не упала на человека, недостойного ее.

С глубоким почтением и совершенною преданностью честь имею пребыть, Вашего Превосходительства Милостивого Государя покорнейший слуга Николай Полевой ${ }^{58}$.

Конец жизни Полевого был омрачен происшествием с его двадцатилетним сыном Никтополеоном, который 22 июля 1845 г. бежал из дома, оставив отцу записку, что является членом тайного общества и по его делам вынужден уехать. Полевой сразу сообщил об этом в III отделение, в результате полиция и жандармы начали розыск. 13 августа Никтополеон был задержан становым приставом в Режицком уезде Витебской губернии за неимением вида (паспорта) и доставлен в Петербург. И хотя вскоре было установлено, что он всё выдумал, а бежал потому, что не поступил в университет, 22 августа по приказу царя он был заключен на 6 месяцев в Шлиссельбургскую крепость, а затем отправлен солдатом на Кавказ ${ }^{59}$.

15 января следующего, 1846 г. Полевой был вынужден просить досрочно выдать ему деньги и отчитывался Дубельту о своих трудах в истекшем году:

Ваше Превосходительство Милостивый Государь,

Позвольте мне поздравить Ваше Превосходительство с новым годом и пожелать Вам всех благ и счастия, коего Вы достойны за всё доброе, чем [1 сл. нрзб] Ваша жизнь, которую да продолжит Бог еще многие годы!

58 Там же. Л. 12.

59 Через пять лет по случаю празднования 25-летия царствования Николая I Никтополеон Полевой был прощен, но оставлен на жительство на Кавказе. В 1850 г. ему разрешили вернуться в Петербург (см. дело III отделения о Никтополеоне Полевом: ГАРФ. Ф. 109. 1 эксп. 1845. Ед. хр. 149; а также: Полтораикий С.Д. Русские достопамятные люди. Заметки и воспоминания // Русская старина. 1892. № 5. С. 237; Гернет М.Н. История царской тюрьмы. М., 1961. Т. 2. С. 402), он выдержал экзамен на учителя гимназии и поступил на службу (см.: Куликов Н.И. Дневник режиссера // Библиотека Театра и искусства. 1913. Кн. 4. С. 19). 
Печально встретил я новый год, растерянный душевно, больной телесно. Прошедший год был мне страшно тяжелым годом. Кроме тяжелой скорби, нанесенной мне моим несчастным сыном, на меня, как град, сыпались горести и скорби. Расстройство дел моего брата ${ }^{60}$, где и я сделался снова жертвою, и бесчестный обман человека, за которого я поручился и должен платить ${ }^{61}$, окончательно усилили недостатки мои, и еще надобно прибавить к тому, что меня обокрали: едва только получил я в прошедшем году Высочайшее пособие и думал сберечь его, как из него похищено было у меня до тысячи рублей ассигнациями и никаких следов похищенного не отыскано. Я старался вознаградить все трудом. Мой обыкновенный урок работы был ежедневно с 4-х часов утра до 3-х пополудни, и опять вечером с 8-ми часов до 11-ти. И хотя, по стеснению моему, должен был я все отдавать за бесценок и все, что выручалось, поглощали мои неумолимые кредиторы, не однажды угрожавшие мне в прошедшем году тюрьмою, но все еще мог бы я биться, если бы наконец безмерный труд не подавил совершенно расстроенного моего здоровья. От утомления я почти лишился употребления правой руки. Врач мой помог мне; я усилил труд, и теперь припадок возобновился сильнее, так, что я едва с трудом двигаю рукою и едва могу, при беспрерывном отдыхе, написать сии строки. Все мои занятия тем разрушаются, хотя и мог бы я еще собрать силы души на труд честный и полезный. В прошедшем году кроме книги «Русские полководцы» ${ }^{62}$, за которую издатель ее ${ }^{63}$ удостоился щедрой награды Государя Императора, деятельно участвовал я в трудах Александра Ивановича Данилевского. Составленная мною, кроме многих других, биография незабвенного героя, генерала Дохтурова, имела счастие заслужить внимание Ваше ${ }^{64}$. Чувства души моей

${ }^{60}$ Имеется в виду Ксенофонт Алексеевич Полевой (1801-1867).

61 По-видимому, речь идет об А.Ф. Смирдине. В 1838 г. он не мог оплатить вексель на 3000 руб.; чтобы выручить его, Полевой выдал ему вексель на эту сумму и потом не раз оказывал ему подобные услуги. Впоследствии Полевому пришлось платить по этим векселям (см.: Дневник Н.А. Полевого. С. 670. Примеч. П.Н. Полевого).

${ }^{62}$ Русские полководцы, или Жизнь и подвиги российских полководцев от времен императора Петра Великого до царствования императора Николая I: жизнеописания, составленные Николаем Полевым. СПб., 1845.

${ }^{63}$ Книгу издал купец первой гильдии, книготорговец и владелец типографии Константин Иванович Жернаков.

64 А.И. Михайловский-Данилевский (1789-1848) - генерал-лейтенант, военный историк. Речь идет о следующем издании: Император Александр I и его сподвижники в 1812, 1813, 1814, 1815 годах: Военная галерея Зимнего дворца...: жизнеописания соч. ген.-лейт. А.И. Михайловского-Данилевского. СПб., 1845-1849. Т. 1-6. Биография Д.С. Дохтурова была помещена во 2-м томе (1845), но про участие Полевого в ее написании там ничего не сказано. 
изложил я в трагедии «Ермак Тимофеевич» ${ }^{65}$ и на днях буду иметь честь доставить Вам мое сочинение «Столетие России, с 1745-го до 1845 года» ${ }^{66}$, которое, смею надеяться, заслужит одобрение Ваше. Но все [надежды?] начинают мои гибнуть теперь среди тяжкой болезни и угнетающей скорби...

Только чувство христианина может еще поддержать меня. «Молись и трудись!» — таков девиз, выбранный мною, но крайность, в коей нахожусь я, заставляет меня беспокоить Ваше Превосходительство. Вручая мне в прошедшем году, марта 7-го, Высочайше пожалованное денежное пособие, состоящее из тысячи рублей серебром, Вы позволили мне надеяться, что в уважение памяти благодетеля моего, князя Александра Николаевича (Голицына. - A.P.), при безграничном великодушии Монаршем, я могу удостоиться его и в нынешнем году. И хоть до годового срока остается еще несколько недель, я осмеливаюсь покорнейше просить Ваше Превосходительство удостоить меня Вашим ходатайством у Его Сиятельства, Графа Алексея Федоровича, о возобновлении мне ныне Высочайшего пособия на сей год. Если есть на то воля милосердного Монарха, ему ли считать время срока милостям! Щедрости Царской нет пределов, а я лишен теперь всякой возможности работать, страдая жестокою болью правой руки моей, и тем более, что по словам почтенного врача моего, если я не дам ей некоторого отдыха, то могу вовсе лишиться употребления ее...

Да будет воля Божия! Может быть, и всего вероятнее, что мне осталось жить недолго. Остаток жизни моей посвящен Царю и Отечеству, пока дышу. Умирая, буду молиться за них!

С глубочайшим почтением и совершенною преданностью, честь имею пребыть Вашего Превосходительства Милостивого Государя покорнейший слуга Николай Полевой ${ }^{67}$.

65 Полевой Н.A. Ермак Тимофеич, или Волга и Сибирь: драматическое представление в 5 д. [в стихах]. СПб., 1845.

66 Полевой Н.А. Столетие России, с 1745 до 1845 года, или Историческая картина достопамятных событий в России за сто лет: Сентября 5-го 1845 г., в день столетнего юбилея, совершившегося со дня рождения кн. Голенищева-КутузоваСмоленского. Ч. 1-2. СПб., 1845-1846. 2-я часть этого сочинения завершалась хроникой царствования Николая I, написанной в панегирическом ключе (с. 355-405). Полевой писал: «Дух Петра Великого почиет на главе его Потомка. <..> Одушевляемый мыслью единства в составе Своей великой империи, Император Николай хочет видеть Русское царство в России и указывает ему на ту великую цель, которую провидение столь явно предназначило России, поставя ее между Западом и Востоком, образуя из нее великого деятеля времен новых, отделив ее самобытным образованием, историею, верою, языком» (с. 402-403).

${ }^{67}$ ГАРФ. Ф. 109. 2 эксп. 1845. Ед. хр. 73. Л. 13-14. 
Пока вопрос рассматривался, Полевой 22 февраля умер, но по приказу императора деньги (1 тыс. руб.) в дальнейшем ежегодно выплачивались его семье ${ }^{68}$.

В 1847 г. в справке III отделения о Полевом говорилось: «Хотя вначале направление Полевого было несколько свободомыслящее, но после 1834 года, когда запрещен был журнал его за критическую статью об одной драме Кукольника и когда в III отделении сделано было ему внушение, он в полном смысле исправился и до конца жизни был ревностнейшим поборником всех благих целей правительства» ${ }^{69}$. В качестве награды за свою деятельность он в течение жизни получил орден Св. Анны III степени и три бриллиантовых перстня ${ }^{70}$.

Подведем итог. В случае с Полевым ІІІ отделение успешно решило стоявшую перед ним задачу. Министерство народного просвещения с санкции императора лишило журналиста возможности последовательно пропагандировать свои реформаторские взгляды в собственном издании, при этом благодаря III отделению литератор лично не подвергся репрессиям и не снискал ореола мученика. Напротив, его время от времени поощряли и морально, и материально (с помощью даров и даже регулярных прямых денежных выплат). Кроме того, руководители III отделения лично устно и письменно указывали ему на отклонения от «верных» взглядов. В результате, если раньше в его деятельности было две стороны: с одной - критика отдельных недостатков и призывы к реформам, а с другой - восхваление монарха и России (причем скорее не ее прошлого и настоящего, а будущего), то впоследствии он отказался от критики и писал в основном тексты, полезные режиму (панегирические монархические статьи в газетах и исторические монархическо-патриотические книги и пьесы), был благодарен царю и III отделению за поддержку и, что любопытно, скомпрометировал себя в глазах оппозиционно настроенных читателей. В среде же лояльной публики правительственная поддержка литератора создавала власти репутацию просвещенной и поддерживающей литературу и искусство.

\footnotetext{
${ }^{68}$ См.: Там же. Л. 16.

69 Там же. Л. 38 об.

70 Там же. Л. 46.
} 


\section{Литература}

Азадовский М.К. История русской фольклористики: В 2 т. М.: РГГУ, 2013. Т. 1. $556 \mathrm{c}$.

Березина В.Г. Журнал Н.А. Полевого «Московский телеграф» и цензура // Вестник Санкт-Петербургского университета. Сер. 2: История, языкознание, литературоведение. 1996. Вып. 3. С. 71-81.

Видок Фиглярин: Письма и агентурные записки Ф.В. Булгарина в III отделение / Публ., сост., предисл. и коммент. А.И. Рейтблата. М.: НЛО, 1998. 722 с.

Гернет М.Н. История царской тюрьмы. М.: Государственное издательство юридической литературы, 1961. Т. 2. 582 с.

Лейбов Р. Немецкий путешественник о Н.А. Полевом // Труды по русской и славянской филологии. Литературоведение. І. (Новая серия). Tapту: Tartu ülikooli kirjas., 1994. С. 242-254.

Осповат А.Л., Тименчик Р.Д. «Печальну повесть сохранить...». М.: Книга, 1985. 307 с. (Судьбы книг).

Рейтблат А.И. Наблюдательный Наблюдатель: Н.И. Греч и III отделение // Литературный факт. 2018. № 10. С. 108-164.

Рейтблат А.И. Пушкин как Булгарин: к вопросу о политических взглядах и журналистской деятельности Ф.В. Булгарина и А.С. Пушкина // Рейтблат А.И. Фаддей Венедиктович Булгарин: идеолог, журналист, консультант секретной полиции: статьи и материалы. М.: Новое литературное обозрение, 2016. С. 57-91.

Шикло А.Е. Исторические взгляды Н.А. Полевого. М.: МГУ, 1981. 223 с.

\section{References}

Azadovskii M.K. Istoriia russkoi fol'kloristiki: $V 2 t$. [The history of Russian folklore studies: In 2 vols]. Moscow, Russian State University for Humanitites Publ., 2013. Vol. 1. 556 p. (In Russ.)

Berezina V.G. ZhurnalN.A.Polevogo "Moskovskii telegraf” i tsenzura [N.A. Polevoy's journal "Moscow Telegraph" and censorship]. Vestnik Sankt-Peterburgskogo universiteta, Seriia 2, Istoriia, iazykoznanie, literaturovedenie, 1996, iss. 3, pp. 71-81. (In Russ.)

Gernet M.N. Istoriia tsarskoi tiur'my [The history of the Tsar prison]. Moscow, Gosudarstvennoe izdatel'stvo iuridicheskoi literatury Publ., 1961. Vol. 2. 582 p. (In Russ.)

Leibov R. Nemetskii puteshestvennik o N.A. Polevom [A German traveler on N.A. Polevoy]. Trudy po russkoi i slavianskoi filologii. Literaturovedenie. I. (Novaia seriia) [Works on Russian and Slavic philology. Literary criticism. I. (New Series)]. Tartu, Tartu ülikooli kirjas., 1994, pp. 242-254. (In Russ.)

Ospovat A.L., Timenchik R.D. "Pechal'nu povest' sokhranit'...” [“To save a sad story...”]. Moscow, Kniga Publ., 1985. 307 p. (In Russ.)

Reitblat A.I. Nabliudatel'nyi Nabliudatel': N.I. Grech i III otdelenie [An observant Observer: Nikolay Grech and the Third Section]. Literaturnyi fakt, 2018, no. 10, pp. 108-164. (In Russ.) 
Reitblat A.I. Pushkin kak Bulgarin: $\mathrm{k}$ voprosu o politicheskikh vzgliadakh i zhurnalistskoi deiatel'nosti F.V. Bulgarina i A.S. Pushkina [Pushkin as Bulgarin: On political views and journalistic activities of F.V. Bulgarin and A.S. Pushkin]. Reitblat A.I. Faddei Venediktovich Bulgarin: ideolog, zhurnalist, konsul'tant sekretnoi politsii: stat'i i materialy [Faddey Venediktovich Bulgarin: ideologist, journalist, consultant of the secret police: essays and materials]. Moscow, Novoe literaturnoe obozrenie Publ., 2016, pp. 57-91. (In Russ.)

Shiklo A.E. Istoricheskie vzgliady N.A. Polevogo [N.A. Polevoy's historical views]. Moscow, Moscow State University Publ., 1981. 223 p. (In Russ.)

Vidok Figliarin: pis'ma i agenturnye zapiski F.V. Bulgarina v III otdelenie [Vidok Figlyarin: F.V. Bulgarin's letters and agent notes for the Third Section], publ., comp. intro. and comment. A.I. Reitblat. Moscow, Novoe literaturnoe obozrenie Publ., 1998. 704 p. (In Russ.)

\title{
Nikolay Polevoy and the Third Section
}

\author{
(C) 2019, Abram Reitblat
}

\begin{abstract}
The purpose of the article is to summarize already known information about N.A. Polevoy's contacts with the Third Section, to introduce into scientific circulation a number of new documents on the subject, including the correspondence of Polevoy and the chief of the Third Section A.Kh. Benckendorff, and on this basis to characterize the writer's contacts with the political police. The Third Section was mainly concerned with monitoring the behavior and attitude of various society sectors to the authorities and its policies, as well as the formation of "public opinion". For this purpose, it sought to take control of journalists. As the author of the article shows, in N.A. Polevoy's case the Third Section successfully solved its task: the leaders of the Section personally (verbally and in writing) pointed out his deviations from the "true" views, and encouraged him morally and financially (through regular cash payments). As a result, while at the beginning of his activity as a critic Polevoy combined individual criticisms and calls for reform with praise of the monarch and Russia (more likely not of its past and present, but of the future), later he refused of criticism and wrote mainly texts useful to the regime - panegyric monarchical articles and historical monarchical-patriotic books and plays. Moreover, he was grateful to the Tsar and the Third Section for support. The facts presented in the article make important clarifications in the history of the relationship between journalism and government in the first half of the 19th century.
\end{abstract}

Keywords: Third Section, Nikolay Polevoy, Alexander Benckendorff, Leonty Dubelt, literature and authorities.

Information about the author: Abram Reitblat, $\mathrm{PhD}$, "Novoe Literaturnoe Obozrenie" / Russian State Art Library, Moscow, Russia, Moscow, Russia. E-mail: reitblat@nlo.magazine.ru

Citation: Reitblat Abram. Nikolay Polevoy and the Third Section. Literaturnyi fakt, 2019, no. 4 (14), pp. 228-251. DOI 10.22455/2541-8297-2019-14-228-251 